\title{
National Cultural Dimensions AND ELECTRONIC CLINICAL RECORDS ACCEPTANCE: AN EXPLORATORY STUDY
}

\author{
Ouiame BENALI IDRISSI, Ph.D. Student \\ Khalid CHAFIK, Professor
}

Research Group "Management \& Information systems," National School of Business and Management of Tangier, Abdelmalek Essaadi University, Tangier, Morocco

\begin{abstract}
The purpose of the present paper is to describe the development of a measurement scale, to assess the impact of the national cultural factors on the electronic clinical records acceptance in the Ibn Sina Hospital Center (CHUIS)in Morocco. The methodology assumed is based on the Churchill paradigm (1979).Thus, our contribution focuses on the exploratory phase, where the items have been analysed using principal components analysis (PCA)and internal consistency with Cronbach's Alpha ( $\alpha$ ). The results show a satisfactory factorial structure and excellent reliability of all the items.
\end{abstract}

\section{KEYWORDS}

National culture-technology acceptance-exploratory factor analysis- measurement scale-reliability.

\section{INTRODUCTION}

Information and Communication Technologies (ICT) have taken crucial importance in our society, and are a strategic and essential tool for economic development.

Morocco launched, in recent years, the Numeric 2013 Plan and the Digital 2020 strategy to promote the information technology by implementing it to all governmental and nongovernmental entities (Administrations, Companies, etc.). In this context, the Ibn Sina Hospital Center (CHUIS) initiated the project "Hospital information system" in 2016. This project aims to integrate the Green cube electronic clinical records (ECR) to facilitate the day-today work for all healthcare professionals. However, the integration of new technology raises the question of user acceptance behavior. Numerous studies have shown that this behavior may be affected by different factors, including national culture values [39].

Therefore, our research aims to study the impact of these factors on the user's intention to accept this new technology in the CHUIS. Thus, we developed a model based on the literature review and the recommendations of previous studies [32]. It is an extension of the technology acceptance model by the national culture factors of Hofstede.

As we adopted a positivist quantitative approach to test our model, we chose the Churchill paradigm as a methodological approach to ensure the validity of the constructs' measurements of the research questionnaire. This paradigm consists of two main phases: an exploratory phase and a confirmatory phase. 
International Journal of Managing Information Technology (IJMIT) Vol.11, No.3, August 2019

In this paper, we will focus only on the exploratory phase and present the principal component and reliability analyses results.

\section{RESEARCHMODEL AND HYPOTHESES}

Based on the literature review and previous studies, we developed our research model from the Technology Acceptance Model (TAM) and the National cultural dimensions of Hofstede [32]. The model combines nine variables, five TAM's variables, and four national cultural variables.

Thus, we suggest twelve hypotheses:

H1: Perceived usefulness has a direct positive effect on the intention to accept the HIS.

H2: Perceived Ease of Use has a direct positive effect on o the intention to accept the HIS.

H3: Perceived Ease of Use has a direct positive effect on the Perceived Usefulness.

H4: Attitude toward using IT has a direct positive effect on Intention to accept the HIS.

H5: Subjective norms have a direct positive effect on the "intention to accept the HIS.

H6: Collectivism has a direct positive effect on the Perceived Usefulness.

H7: Collectivism has a direct positive effect on Perceived ease of use.

H8: Power distance has a direct positive effect on the perceived ease of use.

H9: Uncertainty avoidance has a direct positive effect on Perceived usefulness.

H10: Uncertainty avoidance has a direct positive effect on Perceived Ease of use.

H11: Uncertainty avoidance moderates the relationship between subjective norms and Intention to accept HIS.

H12: Masculinity moderates the relationship between Perceived Ease of Use and intention to accept HIS.

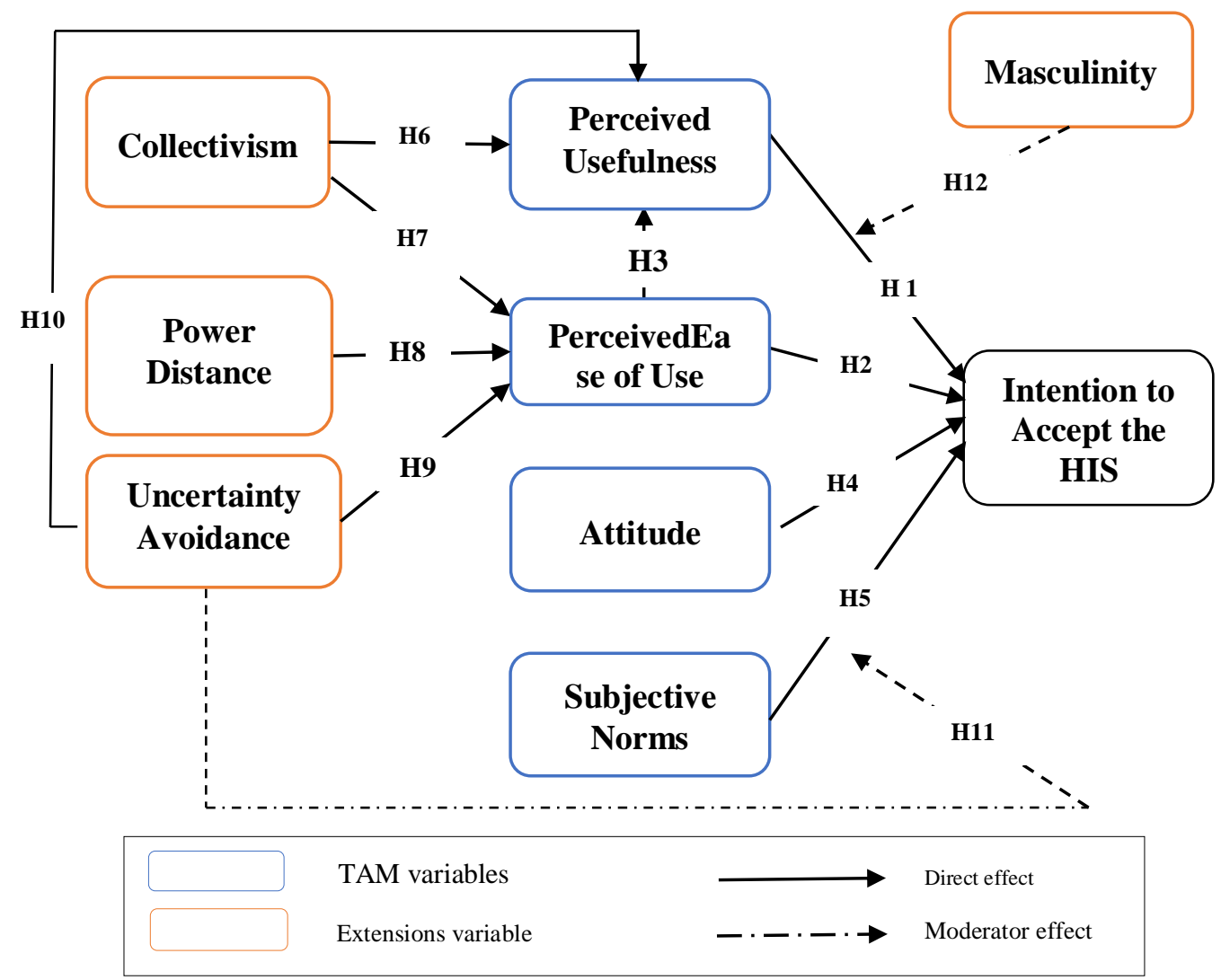

Figure.1: Research Model (updated) 


\section{Research Methodology}

The first version of the questionnaire was elaborated based on the literature review. It was scrutinized in term of structure, wording, translation, and content by selected healthcare professionals and scholars. In order to ensure the validity of the constructs' measurements of the questionnaire, we adopted the Churchill paradigm (1979) [9] as a methodological approach.

The Churchill paradigm consists of several stages grouped into two phases: the exploratory phase and the confirmatory phase.

The first phase consists of specifying the domain of construct, generating the sample of items, collecting data, and purifying measures. The second phase consists of assessing reliability and validity based on a confirmatory study.

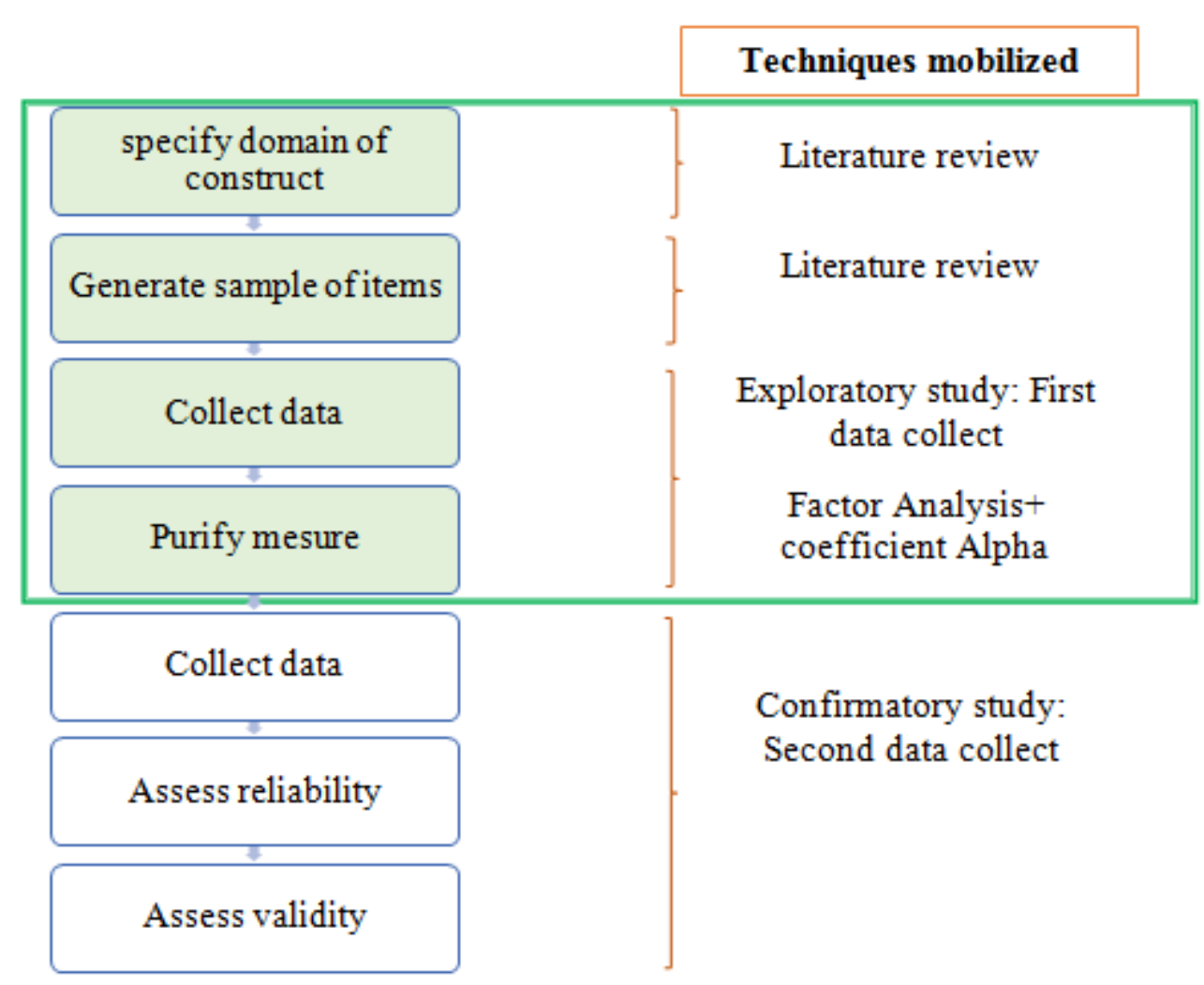

Figure. 2: Suggested Procedure for Developing Better Measures (Churchill, 1979)

In this paper we will focus on the four steps of the exploratory phase, namely: domain of construct specification, items generation, data collection and finally, measures purification, using exploratory factor analysis and Cronbach's Alpha.

\section{SCALE DEVELOPMENT}

\subsection{Domain constructs and Items generation}

All the construct measures used for this research were adapted from previous studies and were anchored on a 7-point Likert scale from "strongly disagree" (1) to "strongly agree" (7). 
International Journal of Managing Information Technology (IJMIT) Vol.11, No.3, August 2019

The measurements were selected according to three criteria: validity, reliability, and research domain (technologies acceptance, healthcare sector, national culture), and then codified and adapted to our research context.

\subsubsection{Perceived Usefulness}

[11] defined Perceived usefulness as "the degree to which a person believes that using a particular system would enhance his or her job performance" [11]. In other words, it represents the extent to which the user sees the technology as having some value by providing the ability to use multiple pathways to do the same task. The following items represent perceived utility:

\begin{tabular}{|c|c|c|}
\hline Codification & Items & Authors \\
\hline $\begin{array}{l}\text { PU_1 } \\
\text { PU_2 } \\
\text { PU_3 } \\
\text { PU_4 }\end{array}$ & $\begin{array}{l}\text { - Using the HIS/ECR would Improve my job performance } \\
\text { - Using the HIS/ECR in my job would increase my work } \\
\text { productivity. } \\
\text { - Using the HIS/ECR would enhance my work effectiveness. } \\
\text { - I would find the HIS/ECR useful to perform my daily } \\
\text { activities. } \\
\text { - The healthcare information system can improve my } \\
\text { professional skills } \\
\text { The healthcare information system can reduce the } \\
\text { paperwork time }\end{array}$ & $\begin{array}{c}{[11][44]} \\
{[31][10]} \\
{[34]} \\
\text { (6Items) }\end{array}$ \\
\hline
\end{tabular}

\subsubsection{Perceived ease of use}

The perceived facility means "the degree to which a person believes that using a particular system would be free of effort"[11]. It refers to the extent that the use of technology is perceived as relatively effortless. Technologies that are perceived user-friendly are more likely to be accepted and used by potential users. The variable "Perceived ease of use" is explained by four items:

\begin{tabular}{|c|c|c|}
\hline Codification & \multicolumn{1}{|c|}{ Items } & Authors \\
\hline PEOU_1 & $-\quad \begin{array}{l}\text { Learning to operate the HIS/ECR would be easy for me. } \\
\text { PEOU_2 }\end{array}$ & $\left.\begin{array}{l}{[11][44]} \\
\text { It would be easy for me to become skillful at using the }\end{array}\right]$ \\
HIS/ECR. & $\begin{array}{l}\text { My interaction with the HIS/ECR would be clear and } \\
\text { (4 Items) }\end{array}$ \\
PEOU_3 & $\begin{array}{l}\text { understandable } \\
\text { PEOU_4 }\end{array}$ & I would find the HIS/ECR easy to use. \\
\hline
\end{tabular}

\subsubsection{Attitude}

[43] considers Attitude as an «Affect » and define it as "feelings of joy, pleasure, disgust, or displeasure associated with a particular act." It is an individual's internal evaluation of an object [30]. According to [13], attitude is "a psychological tendency that is expressed by evaluating a particular entity with some favor or disfavor." It expresses a positive or negative assessment of commitment [17];[11]. The variable is represented by the following items: 
International Journal of Managing Information Technology (IJMIT) Vol.11, No.3, August 2019

\begin{tabular}{|c|c|c|}
\hline Codification & Items & Authors \\
\hline $\begin{array}{l}\mathrm{ATT}_{-} 1 \\
\mathrm{ATT}_{2} \\
\mathrm{ATT}_{2} 3\end{array}$ & $\begin{array}{ll}\text { - } & \text { Using HIS/ECR is a good idea. } \\
\text { - } & \text { Using HIS/ECR is beneficial. } \\
\text { - } & \text { Using HIS/ECR is pleasant. }\end{array}$ & $\begin{array}{c}{[11][27][45]} \\
{[26][20][38][14]} \\
(3 \quad \text { Items })\end{array}$ \\
\hline
\end{tabular}

\subsubsection{Subjective norms}

The concept of subjective norms or social influence comes from the Theory of Reasoned Action [16],the Theory of Planned Behavior [1] and the Technology Acceptance Model (TAM2) [45].

Subjective norms refer to the individual perceived social pressure to perform or not perform a behavior regarding the use of a new system [1]. According to [46], subjective norms refer to "the person's perception that most people who are important to him think he should or should not perform, the behavior in question." Based on the literature review, two items explain the "Subjective norms" variable:

\begin{tabular}{|c|c|c|}
\hline Codification & Items & Authors \\
\hline NS_1 & $\begin{array}{l}\text { - People who influence my behavior think that I should use } \\
\text { the HIS/ECR. } \\
\text { - People who are important to me think that I should use the } \\
\text { HIS/ECR. }\end{array}$ & $\begin{array}{l}{[46][38]} \\
{[49][35]} \\
(2 \text { Items) }\end{array}$ \\
\hline
\end{tabular}

\subsubsection{Masculinity}

Masculinity is a psychological gender measure, indicating whether an individual supports masculine values against feminine values [3];[22]. "Masculine" values are generally characterized by self-confidence, hardness, and concern for material wealth, as opposed to femininity values that are characterized by modesty, tenderness, and concern for the quality of life [21].

In other words, Individuals who support masculine values include the objectives of remuneration, recognition, advancement, and challenge; while those who include feminine values are interested in the hierarchy (Labour Relations), Collaboration (Working in Harmony), Living Environment (Nice Place to Live) and Job Security [21]. Nine items explain Masculinity: 
International Journal of Managing Information Technology (IJMIT) Vol.11, No.3, August 2019

\begin{tabular}{|c|c|c|}
\hline Codification & Items & Authors \\
\hline $\begin{array}{l}\text { MAS_1 } \\
\text { MAS_2 }\end{array}$ & $\begin{array}{l}\text { - } \quad \text { Money and material things are important. } \\
\text { - } \quad \text { Men are supposed to be assertive, ambitious and tough }\end{array}$ & $\begin{array}{c}{[24]} \\
(2 \text { Items })\end{array}$ \\
\hline $\begin{array}{l}\text { MAS_3 } \\
\text { MAS_4 }\end{array}$ & $\begin{array}{l}\text { - It is important to achieve in life even if personal sacrifices } \\
\text { are made as a result. } \\
\text { - Advancing one's career goal is important more than having a } \\
\text { friendly work environment. }\end{array}$ & $\begin{array}{l}{[10][24]} \\
(2 \text { Items) }\end{array}$ \\
\hline $\begin{array}{l}\text { MAS_5 } \\
\text { MAS_6 } \\
\text { MAS_7 }\end{array}$ & $\begin{array}{l}\text { - It is preferable to have a man in a high-level position rather } \\
\text { than a woman } \\
\text { - There are some jobs in which a man can always do better } \\
\text { than a woman. } \\
\text { - It is more important for men to have a professional career } \\
\text { than it is for women to have a professional career. } \\
\text { - Solving organizational problems usually requires an active } \\
\text { forcible approach that is more typical of men } \\
\text { - Women do not value recognition and promotion in their } \\
\text { work as much as men do. }\end{array}$ & $\begin{array}{c}{[18]} \\
{[2][39]} \\
(5 \text { Items })\end{array}$ \\
\hline
\end{tabular}

\subsubsection{Power Distance}

[21] define the Power distance as "the extent to which a society accepts the fact that power in institutions and organizations is distributed unequally." It is also "the degree to which members of an organization or society expect and agree that power should be shared unequally" [5]. The power distance is explained by the following items:

\begin{tabular}{|c|c|c|}
\hline Codification & Items & Authors \\
\hline $\begin{array}{l}\text { PD_1 } \\
\text { PD_2 } \\
\text { PD_3 }\end{array}$ & $\begin{array}{l}\text { - Managers should make most decisions without consulting } \\
\text { subordinates. } \\
\text { - Managers should not ask subordinates for advice because } \\
\text { they might appear less powerful. } \\
\text { - Decision-making power should stay with top management in } \\
\text { the organization and not be delegated to lower-level } \\
\text { employees. } \\
\text { - Employees should not question their manager's decision. } \\
\text { - A manager should perform work that is difficult and } \\
\text { important, and delegate tasks which are repetitive and } \\
\text { mundane to subordinates. } \\
\text { - High-level managers should receive more privileges than } \\
\text { lower employees. } \\
\text { Managers should be careful not to ask the opinions of } \\
\text { subordinates too frequently; otherwise, the managers might } \\
\text { appear to be weak and incompetent. }\end{array}$ & $\begin{array}{c}{[18][2][39]} \\
\text { (7Items) }\end{array}$ \\
\hline
\end{tabular}

\subsubsection{Collectivism}

Collectivism "is characterized by a tight social framework in which people distinguish between in-groups and out-groups; they expect their in-group (relatives, clan, organizations) to look after them, and in exchange for that they feel they owe absolute loyalty to it."[21]. This national 
International Journal of Managing Information Technology (IJMIT) Vol.11, No.3, August 2019

dimension is also a measure "to which individuals express pride, loyalty, and cohesiveness in their organizations or families" [25]. The following items explain collectivism:

\begin{tabular}{|c|c|c|}
\hline Codification & Items & Authors \\
\hline $\begin{array}{l}\text { COLL_1 } \\
\text { COLL_2 } \\
\text { COLL_3 } \\
\text { COLL_4 } \\
\text { COLL_5 }\end{array}$ & $\begin{array}{l}\text { - Being accepted as a member of a group is more important } \\
\text { than having autonomy and independence on the job. } \\
\text { - Group success is more important than individual success. } \\
\text { - Being loyal to a group is more important than individual } \\
\text { gain. } \\
\text { - Individual rewards are not as important as group welfare. } \\
\text { - It is more important for a manager to encourage loyalty and } \\
\text { sense of duty in subordinates than it is to encourage } \\
\text { individual initiative. }\end{array}$ & $\begin{array}{c}{[18][2]} \\
{[39]} \\
\text { (5Items) }\end{array}$ \\
\hline
\end{tabular}

\subsubsection{Uncertainty Avoidance}

According to [21], Uncertainty Avoidance describes "the extent to which a society feels threatened by uncertain and ambiguous situations." The uncertainty tolerance is determined partly by culture [23]. This cultural dimension is explained by the following items:

\begin{tabular}{|c|c|c|}
\hline Codification & \multicolumn{1}{c|}{ Items } & Authors \\
\hline UA_1 & $-\begin{array}{l}\text { Rules and regulations are important because they } \\
\text { inform workers what the organization expects of them. } \\
\text { UA_2 }\end{array}$ & $\begin{array}{l}\text { Order and structure are essential in a work } \\
\text { environment. }\end{array}$ \\
UA_3 & $-\begin{array}{l}\text { It is important to have job requirements and } \\
\text { instructions spelled out in details so that people always } \\
\text { know what they are expected to do. }\end{array}$ & {$[18][2]$} \\
UA_4 & $-\begin{array}{l}\text { I prefer a bad situation that I know about to an } \\
\text { uncertain situation which might be better. }\end{array}$ \\
UA_5 & $-\begin{array}{l}\text { Providing opportunities to be innovative is more } \\
\text { important than requiring standardized work procedures. }\end{array}$ \\
UA_6 & $-\begin{array}{l}\text { People should avoid making changes when their } \\
\text { outcomes are uncertain. }\end{array}$ & \\
\hline
\end{tabular}

\subsubsection{Intention to accept HIS}

The intention is defined by[16] as an intermediate variable between attitude and behavior. It shows the desire, the wish, the determination, or the will to express behavior. It also represents a person's conscious level of exerting effort to achieve behavior [13], [12] point out that the intention to use a technology represents the probability that a user will intend to use the technology. 
International Journal of Managing Information Technology (IJMIT) Vol.11, No.3, August 2019

The intention is represented by the following items:

\begin{tabular}{|l|l|c|}
\hline Codification & \multicolumn{1}{|c|}{ Items } & Authors \\
\hline INACC_1 & & \\
INACC_2 & $-\quad$ I intend to use HIS/ECR when it becomes available. & {$[26][48][7]$} \\
INACC_3 & $-\quad$ I would use HIS /ECR to do clinical services & [33] [49] \\
INACC_4 & $-\quad$ I would use HIS /ECR to do nonclinical services & (4 Items) \\
& $-\quad$ I would use HIS/ECR in my work frequently & \\
\hline
\end{tabular}

\subsection{Data Collection}

In March 2018, we conducted a survey among health care professionals in Ibn Sina hospital center, In Rabat Morocco. Participants filled the survey via "SurveyMonkey," an online survey tool to collect data.

According to[37], it is generally advisable to collect samples from 10 to 30 people, in exploratory studies. In this first survey, we obtained 17 filled questionnaires.

Most of the respondents were females (70.6\%), between 25 and 40 years old. 35.3\% of them are nurses and have been working in the hospital for less than five years' seniority.

\subsection{Measures purification criterions}

The questionnaire was first analyzed through an Exploratory Factor Analysis (EFA), and then through a reliability analysis. These are the two steps generally advocated by Churchill paradigm during the exploratory phase [19].

The objective of these analyses is to remove items with unsatisfactory psychometric qualities.

\subsubsection{Exploratory factor analysis}

According to [8], the EFA explores the dataset and tests predictions, to uncover intricate patterns. It summarizes the data into a reduced number of factors to maximize the variance. In order to do so, we chose the Principal component analysis (PCA) as it is the most widely used technique to do this [29]. It is a tool used in exploratory data analysis and predictive models, and its application passes through several stages.

Two tests attest the data factorization: the Kaiser-Meyer-Olkin measure of sampling adequacy (KMO) and Bartlett's test Sphericity[15]

- The KMO tests whether the selected variables form a coherent set and measure accurately the construct[6]. The range of $\mathrm{KMO}$ is between 0 and 1, and accepted valuesare higher than 0.5 [28]; [50].

- The Bartlett test examines the matrix of correlations in its entirety and provides the probability of the null hypothesis that all correlations are zero. It must have a significance level of $\mathrm{p}<.05$ for EFA to be suitable [15]; [50]. 
International Journal of Managing Information Technology (IJMIT) Vol.11, No.3, August 2019

The PCA can be executed to verify the variables' dimensionality.If the analyze highlights only one factor, then the construct is one dimensional. If it highlights several factors, then it is a multidimensional construct. The number of factors is retained based on the Kaiser criterion and the variance percentage criterion.

- The Kaiser criterion consists in retaining only factors with eigen values greater than 1 [6].

- In the Variance percentage criterion, the researcher should fix a cut-off in advance, corresponding to the minimum variance percentage. According to [36], In the social sciences, the explained variance is generally as low as 50\%-60\%. In our study, we fixed $50 \%$ as a minimum total explained variance.

In order to facilitate the factors' interpretation and to simplify the solutions, we choose Varimax Rotation method as itprovides a simple structure and it is the most common form of the rotational methods for EFE [42].

We interpreted the extracted factors by examining the component matrix (loadings or factor weights) after rotation. The loadings represent the correlation between a variable and a factor [28]. A good rule of thumb for the minimum loading of an item is 0.50 or higher [4].

In the case of a multi-dimensional construct, the items with loading less than 0.5 or higher than 0.3 on several axes at once are eliminated [37].

\subsubsection{Reliability analysis}

Reliability refers to the consistency of a test or measurement[47]. It can be estimated in different ways.

We adopted in our study the internal consistency method using Cronbach's Alpha $(\alpha)$ as a Measure since it is the most used index of the reliability [40]. The more its value is closer to 1 , the more reliability is strong. Commonly, we accept values greater than 0.7 [41].

The table below summarises the indicators used in the factor analysis and reliability analysis to purify our measures.

Table 1: Measures purification indicators

\begin{tabular}{|l|l|}
\hline Indicators & Acceptation criteria \\
\hline KMO & $\geq 0.5$ \\
\hline Bartlett's Test & $0.0 \geq$ Signifiance $\leq 0.05$ \\
\hline Eigenvalues & $\geq 1$ \\
\hline \%Variance & $\geq 0.5$ \\
\hline Communality & $\geq 0.5$ \\
\hline Component Matrix & $\geq 0.5$ \\
\hline Cronbach Alpha & $\geq 0.7$ \\
\hline
\end{tabular}

All the Analyses has been carried out on SPSS software version 25. The main results are presented below. 
International Journal of Managing Information Technology (IJMIT) Vol.11, No.3, August 2019

\section{RESULTS AND DATA ANALYSIS}

\subsection{Perceived Usefulness}

Table.2: Dimensionality and reliability analyses of Perceived Usefulness

\begin{tabular}{|c|c|c|c|c|}
\hline Items & $\begin{array}{c}\text { KMO and Bartlett's } \\
\text { Test }\end{array}$ & Variance explained & Communalities & Loadings \\
\hline PU_1 & \multirow{6}{*}{$\begin{array}{l}\text { Approx. Chi-Square }= \\
62.887 \\
\text { ddl }=15 \\
\text { Sig. }=\mathbf{. 0 0 0}\end{array}$} & \multirow[t]{3}{*}{ Eigenvalues $=\mathbf{3 . 9 8 4}$} & .826 & .909 \\
\hline PU_2 & & & .671 & .819 \\
\hline PU_3 & & & .893 & .945 \\
\hline PU_4 & & \multirow[t]{3}{*}{$\%$ Variance $=\mathbf{6 6 . 3 9 9}$} & .558 & .747 \\
\hline PU_5 & & & .645 & .803 \\
\hline PU_6 & & & .391 & .625 \\
\hline \multicolumn{3}{|c|}{ Cronbach Alpha } & \multicolumn{2}{|c|}{0.885} \\
\hline
\end{tabular}

Extraction Method: Principal Component Analysis.

Results showed that the KMO is satisfactory, and the Barlett 's test is significant. However, PU_6's commonality is less than 0.50 , which leads us to consider its elimination.

The first total explained variance analysis of the Perceived Usefulness measure scale showed that the first item represented $66 \%$ of the variance explained. However, after the elimination of item PU_6, we found, after a second analysis, that the first component represents $73 \%$ of the variance explained.

Cronbach's alpha with the PU_6 item is 0.885 . After its elimination, we obtained an alpha equal to 0.898 . Consequently, we decided to delete item PU_6.

\subsection{Perceived ease of use}

Table.3: Dimensionality and reliability analysesof Perceived Ease of Use

\begin{tabular}{|c|c|c|c|c|}
\hline Items & $\begin{array}{c}\text { KMO and Bartlett's } \\
\text { Test }\end{array}$ & Variance explained & Communalities & Loadings \\
\hline PEOU_1 & $\mathrm{KMO}=\mathbf{. 7 3 5}$ & Eigenvalues $=\mathbf{2 . 5 8 5}$ & .863 & .929 \\
\hline PEOU_2 & \multirow{3}{*}{$\begin{array}{l}\text { Approx. } \\
\text { Square }=25.654 \\
\text { ddl }=6 \\
\text { Sig. }=.000\end{array}$} & $\%$ Variance $=$ & .220 & .469 \\
\hline PEOU_3 & & \multirow[t]{2}{*}{64.628} & .752 & .867 \\
\hline PEOU_4 & & & .751 & .867 \\
\hline \multicolumn{3}{|c|}{ Cronbach Alpha } & \multicolumn{2}{|c|}{0.774} \\
\hline
\end{tabular}

Extraction Method: Principal Component Analysis.

The KMO is satisfactory, and the Barlett's test is significant.Based on table 3 results, the communality and factorial weight of item PEOU_2 is less than 0.50. The first-factor analysis showed that the first component represented $64 \%$ of the variance explained. However, after the elimination of item PEOU_2, we found that the first component represents $81 \%$ of the variance explained.

Cronbach's alpha without the elimination of item PEOU_2 is 0.774. After the elimination of this item, we obtained an alpha equal to 0.881 . Consequently, we decided to delete item PEOU_2. 
International Journal of Managing Information Technology (IJMIT) Vol.11, No.3, August 2019

\subsection{Attitude}

Table.4: Dimensionality and reliability analyses of Attitude

\begin{tabular}{|c|c|c|c|c|}
\hline Items & $\begin{array}{c}\text { KMO and Bartlett's } \\
\text { Test }\end{array}$ & Variance explained & Communalities & Loadings \\
\hline ATT_1 & \multirow{3}{*}{$\begin{array}{l}\text { KMO }=. \mathbf{6 1 3} \\
\text { Approx.Chi- } \\
\text { Square }=38.948 \\
\text { ddl }=3 \\
\text { Sig. }=\mathbf{. 0 0 0}\end{array}$} & \multirow{3}{*}{$\begin{array}{l}\text { Eigenvalues : } \\
\text { Axe } 1: \mathbf{2 . 3 4 0} \\
\text { \% Variance }=\mathbf{7 7 . 9 9 9}\end{array}$} & .907 & .952 \\
\hline ATT_2 & & & .911 & .955 \\
\hline ATT_3 & & & .522 & .722 \\
\hline \multicolumn{3}{|c|}{ Cronbach Alpha } & \multicolumn{2}{|c|}{0.842} \\
\hline
\end{tabular}

Extraction Method: Principal Component Analysis

The KMO is moderately satisfactory, and the Bartlett sphericity test is significant. All items have a satisfactory Communality, and a factor weight is higher than 0.50 .

The factor analysis reveals that the scale is unidimensional, and the first component represents almost $78 \%$ of the variance explained.

\subsection{Subjective Norms}

Table.5: Dimensionality and reliability analyses of Subjective Norms

\begin{tabular}{|c|c|c|c|c|}
\hline Items & $\begin{array}{c}\text { KMO and Bartlett's } \\
\text { Test }\end{array}$ & Variance explained & Communalities & Loadings \\
\hline SN_1 & $\mathrm{KMO}=\mathbf{. 5 0 0}$ & $\begin{array}{l}\text { Eigenvalues: } \\
\text { Axe } 1: \mathbf{1 . 5 7 8}\end{array}$ & .789 & .888 \\
\hline SN_2 & $\begin{array}{l}\text { Approx. } \\
\text { Square }=5.902 \\
\text { ddl }=1 \\
\text { Sig. }=\mathbf{. 0 1 5}\end{array}$ & $\%$ Variance $=\mathbf{7 8 . 9 1 2}$ & .789 & .888 \\
\hline \multicolumn{3}{|c|}{ Cronbach Alpha } & \multicolumn{2}{|c|}{0.727} \\
\hline
\end{tabular}

Extraction Method: Principal Component Analysis

The KMO is satisfactory, and the sphericity test is significantly less than 0.05 .

All items have a satisfactory communality and a factor weight greater than 0.50 .

The factor analysis reveals that the scale is unidimensional, and the first component represents $78 \%$ of the variance explained. Cronbach's alpha expresses a satisfactory coefficient.

\subsection{Collectivism}

Table. 6: Dimensionality and reliability analyses of Collectivism

\begin{tabular}{|c|c|c|c|c|}
\hline Items & $\begin{array}{c}\text { KMO and Bartlett's } \\
\text { Test }\end{array}$ & $\begin{array}{l}\text { Variance } \\
\text { explained }\end{array}$ & Communalities & Loadings \\
\hline COLL_1 & \multirow{2}{*}{$\mathrm{KMO}=.679$} & \multirow{2}{*}{$\begin{array}{l}\text { Eigenvalues: } \\
\text { Axe } 1: \mathbf{3 . 1 1 7}\end{array}$} & .782 & .884 \\
\hline COLL_2 & & & .507 & .712 \\
\hline COLL_3 & \multirow{3}{*}{$\begin{array}{l}\text { Approx. } \\
\text { Square }=43.420 \\
\text { ddl }=10\end{array}$} & \multirow{3}{*}{$\begin{array}{l}\text { \%Variance } \\
\text { 62.341 }\end{array}$} & .871 & .933 \\
\hline COLL_4 & & & .786 & .886 \\
\hline COLL_5 & & & .172 & .415 \\
\hline \multicolumn{3}{|c|}{ Cronbach Alpha } & \multicolumn{2}{|c|}{0.814} \\
\hline
\end{tabular}


International Journal of Managing Information Technology (IJMIT) Vol.11, No.3, August 2019

The KMO is satisfactory. However, by removing the item: COLL_5, which had a communality of 0.172 , the KMO improved to 0.705 . The sphericity test is also significant.

All items have a satisfactory factorial weight and also satisfactory communalities, except for item COLL_5.

The first analysis of the total explained variance of the Collectivism measurement scale showed that the first item represented $62 \%$ of the variance explained. However, after the elimination of item COLL_5, we found, after a second analysis, that the first component represents $74 \%$ of the variance explained.

Cronbach's alpha with COLL_5 is equal to 0.814. After its elimination, the alpha is equal to 0.880. Consequently, we decided to delete item COLL_5.

\subsection{Uncertainty Avoidance}

Table. 7: Dimensionality and reliability analyses of Uncertainty Avoidance

\begin{tabular}{|c|c|c|c|c|c|}
\hline Items & KMO and Bartlett's & Variance & Communalities & \multicolumn{2}{|c|}{ Loadings } \\
\hline UA 1 & \multirow{6}{*}{$\begin{array}{l}\text { Approx. Chi-Square }= \\
\quad 30.641 \\
\text { ddl }=15 \\
\text { Sig. }=\mathbf{. 0 1 0}\end{array}$} & \multirow{4}{*}{$\begin{array}{l}\text { Eigenvalues : } \\
\text { Axe } 1: \mathbf{2 . 6 1 7} \\
\text { Axe } 2: \mathbf{1 . 4 5 9}\end{array}$} & .651 & .602 & .537 \\
\hline UA_2 & & & .875 & .933 & -.063 \\
\hline UA_3 & & & .845 & .917 & .061 \\
\hline UA_4 & & & .815 & .197 & .881 \\
\hline UA_5 & & \multirow{2}{*}{$\begin{array}{l}\text { \%Variance } \\
67.939\end{array}$} & .185 & .369 & .222 \\
\hline UA_6 & & & .705 & -.045 & .839 \\
\hline \multicolumn{3}{|c|}{ Cronbach Alpha } & \multicolumn{3}{|c|}{0.693} \\
\hline
\end{tabular}

Extraction Method: Principal Component Analysis. Rotation Method: Varimax with Kaiser Normalization. a. Rotation converged in 3 iterations.

The KMO is moderately satisfactory, and the test of sphericity is also significant. The factor analysis was done on a 2-dimensional proposal. The first two components represent $67 \%$ of the variance explained. However, after the elimination of UA_5, we found, after a second analysis, that the first two components represent $79 \%$ of the variance explained.

Findings show that all items have a communality greater than 0.5 except item UA_5. We also see that the two items, UA_1 and UA_5, have high saturations on both axes, which leads us to think about their elimination.

Cronbach's alpha with UA_5 was 0.693. The results show that the value of Cronbach's Alpha without UA_1 decreased to 0.592, while Cronbach's Alpha value without UA_5 increased to 0.700. Consequently, we decide to keep UA_1 and delete UA_5.

\subsection{Intention to accept}

Table. 8: Dimensionality and reliability analyses of Intention to accept

\begin{tabular}{|c|c|c|c|c|}
\hline Items & $\begin{array}{c}\text { KMO and Bartlett's } \\
\text { Test }\end{array}$ & Variance explained & Communalities & Loadings \\
\hline INACC_1 & \multirow{4}{*}{$\begin{array}{l}\text { KMO }=. \mathbf{6 8 8} \\
\text { Approx. } \\
\text { Square }=42.325 \\
\text { ddl }=6 \\
\text { Sig. }=\mathbf{. 0 0 0}\end{array}$} & \multirow{4}{*}{$\begin{array}{l}\text { Eigenvalues } \\
\text { Axe : } \mathbf{2 . 7 6 1}\end{array}$} & .889 & .943 \\
\hline INACC_2 & & & .738 & .859 \\
\hline INACC_3 & & & .200 & .447 \\
\hline INACC_4 & & & .934 & .967 \\
\hline \multicolumn{3}{|c|}{ Cronbach Alpha } & \multicolumn{2}{|c|}{0.829} \\
\hline
\end{tabular}

Extraction Method: Principal Component Analysis 
The KMO is satisfactory, and the Bartlett sphericity test is significant. All items have a satisfactory factorial weight and satisfactory communalities as well, except for INACC_3. The first total explained variance analysis of the intent-to-accept measure scale showed that the first item represented $69 \%$ of the variance explained. However, after the elimination of item INACC_3, we found that the first component represents $87 \%$ of the variance explained.

The Cronbach alpha with item INACC_3 is 0.829. After its elimination, it increased to 0.926 . Consequently, we decide to delete item INACC_3.

\subsection{Power Distance}

Table. 9: Dimensionality and reliability analyses of Power distance

\begin{tabular}{|c|c|c|c|c|c|}
\hline Items & $\begin{array}{c}\text { KMO and Bartlett's } \\
\text { Test }\end{array}$ & $\begin{array}{l}\text { Variance } \\
\text { explained }\end{array}$ & Communalities & \multicolumn{2}{|c|}{ Loadings } \\
\hline PD_1 & \multirow{7}{*}{$\begin{array}{l}\text { Approx. Chi-Square= } \\
\quad 59.080 \\
\text { ddl }=21\end{array}$} & \multirow{7}{*}{$\begin{array}{l}\text { Eigenvalues } \\
\text { Axe } 1: \mathbf{3 . 7 2 1} \\
\text { Axe } 2: \mathbf{1 . 3 7 3}\end{array}$} & .766 & .830 & .278 \\
\hline PD_2 & & & .448 & .667 & -.056 \\
\hline PD_3 & & & .782 & .245 & .849 \\
\hline PD_4 & & & .810 & .885 & .167 \\
\hline PD_5 & & & .716 & .839 & .111 \\
\hline PD_6 & & & .876 & .031 & .935 \\
\hline PD_7 & & & .696 & .737 & .392 \\
\hline \multicolumn{3}{|c|}{ Cronbach Alpha } & \multicolumn{3}{|c|}{0.825} \\
\hline
\end{tabular}

Extraction Method: Principal Component Analysis Rotation Method: Varimax with Kaiser Normalization. a. Rotation converged in 3 iterations.

The KMO is moderately satisfactory, and the test of sphericity is also significant.

The first-factor analysis was made on a proposal of 2 dimensions. The first two components represent $72 \%$ of the variance explained. However, after the removal of item PD_2 and PD_7, we found that the first two components represent $83 \%$ of the variance explained.

All items have a quality of representation greater than 0.5 except item PD_2. We also note that item PD_7 contributes to more than one-factor axis. These results lead us to think about eliminating items PD_2 and PD_7.

According to the results, the initial alpha is very satisfactory (with a value of 0.825 ) for all the items, however, and after deleting the two items (PD_2 and PD_7), we obtained an alpha of 0.793. Consequently, we decide to delete these two items. 
International Journal of Managing Information Technology (IJMIT) Vol.11, No.3, August 2019

\subsection{Masculinity}

Table. 10: Dimensionality and reliability analyses of Masculinity

\begin{tabular}{|c|c|c|c|c|c|c|}
\hline Items & KMO and & Variance & Communalities & \multicolumn{3}{|c|}{ Loadings } \\
\hline MAS_1 & \multirow[b]{3}{*}{$\begin{array}{l}\text { Approx.Chi- } \\
\text { Square= }\end{array}$} & \multirow{3}{*}{$\begin{array}{l}\text { Eigenvalues } \\
\text { Axe } 1: \mathbf{3 . 6 3 9} \\
\text { Axe } 2: \mathbf{1 . 7 2 8}\end{array}$} & .578 & .571 & .151 & .478 \\
\hline MAS_2 & & & .836 & -.124 & .084 & .902 \\
\hline MAS_3 & & & .709 & -.078 & .759 & .356 \\
\hline MAS_4 & 56.881 & Axe $3: \mathbf{1 . 2 0 0}$ & .762 & .096 & .863 & -.093 \\
\hline MAS_5 & $\mathrm{ddl}=36$ & & .729 & .835 & -.176 & .020 \\
\hline MAS_6 & & $\%$ Variance & .813 & .827 & .358 & .013 \\
\hline MAS_7 & Sig. = .015 & 72.963 & .589 & .720 & -.001 & -.266 \\
\hline MAS_8 & & & .790 & .834 & -.192 & .239 \\
\hline MAS_9 & & & .761 & .810 & .198 & -.257 \\
\hline
\end{tabular}

Extraction Method: Principal Component Analysis. Rotation Method: Varimax with Kaiser Normalization. a. Rotation converged in 5 iterations.

The KMO was satisfactory, and the Barlett sphericity test was significant.All items' communalities are more significant than 0.5. We also note that the three items, MAS_1, MAS_3, and MAS_6, contribute to more than one-factor axis, which leads us to think about eliminating them.

According to the results, the initial alpha is satisfactory (with a value of 0.726 ) for all the items, however, and after deleting the three items (MAS_1, MAS_3, and MAS_6) from the analysis, we obtained an alpha of 0.560 . This value is insufficient for exploratory analysis. Consequently, we decide to keep these items.

\section{Conclusion}

This research study aimed to purify measures, used in the questionnaire, tested via an exploratory factor analysis among the healthcare professionals in the Ibn Sina Hospital Center (CHUIS) in Morocco.

The factor and reliability analyses led us to eliminate seven items that reduced the psychometric quality of the proposed measures. The eliminated items are:

- PU_6 (Perceived Usefulness' measure scale),

- PEOF_2 (Perceived ease of use's measure scale)

- PD_2(Power distance measure scale),

- PD_7 (Power distance measure scale),

- COLL_5 (Collectivism measure scale),

- UA_5(Uncertainty avoidance's measure scale)

- INACC_3 (Intention to accept's measure scale)

Finally, the confirmatory phase we intend to carry out will validate these results and test whether these scales could predict the users 'acceptance of the ECR, as expected. 
International Journal of Managing Information Technology (IJMIT) Vol.11, No.3, August 2019

\section{REFERENCES}

[1] Ajzen, I. (1991). The theory of planned behavior. Organizational behavior and human decision processes, 50(2), 179-211.

[2] Al-Sukkar, A. S. (2005). The application of information systems in the Jordanian banking sector: a study of the acceptance of the internet.

[3] Bem, S. L. (1981). Gender schema theory: A cognitive account of sex typing. Psychological review, 88(4), 354.

[4] Burton, L. J., \& Mazerolle, S. M. (2011). Survey instrument validity part I: Principles of survey instrument development and validation in athletic training education research. Athletic Training Education Journal, 6(1), 27-35.

[5] Carl, D., Gupta, V. and Javidan, M. (2004) 'Power Distance', in R.J. House, P.J. Hanges, M. Javidan, P.W. Dorfman and V. Gupta (eds.) Culture, Leadership, and Organizations: The GLOBE Study of 62 Societies, Sage: Thousand Oaks, CA, pp: 513-563.

[6] Carricano, M., Poujol, F., \&Bertrandias, L. (2010). Analyse de données avec SPSS®. Pearson Education France.

[7] Chang, M. K. (1998). Predicting unethical behavior: a comparison of the theory of reasoned action and the theory of planned behavior. Journal of business ethics, 17(16), 1825-1834.

[8] Child, D. (2006). The essentials of factor analysis. A\&C Black.

[9] Churchill Jr, G. A. (1979). A paradigm for developing better measures of marketing constructs. Journal of marketing research, 16(1), 64-73.

[10] Cyr, D., Gefen, D., \&Walczuch, R. (2017). Exploring the relative impact of biological sex and masculinity-femininity values on information technology use. Behaviour \& Information Technology, 36(2), 178-193.

[11] Davis, F. D. (1989). Perceived usefulness, perceived ease of use, and user acceptance of information technology. MIS quarterly, 319-340.

[12] Dodds, W. B., Monroe, K. B., \& Grewal, D. (1991). Effects of price, brand, and store information on buyers' product evaluations. Journal of marketing research, 28(3), 307-319.

[13] Eagly, A. H., \&Chaiken, S. (1993). The psychology of attitudes. Harcourt Brace Jovanovich College Publishers.

[14] Escobar-Rodríguez, T., \&Bartual-Sopena, L. (2015). Impact of cultural factors on attitude toward using ERP systems in public hospitals. Revista de Contabilidad, 18(2), 127-137

[15] Evrard, Y., Pras, B., Roux, E., Desmet, P., Dussaix, A. M., \&Lilien, G. L. (2009). MarketFondements et méthodes des recherches en marketing (No. hal-00490724).

[16] Fishbein, M., \&Ajzen, I. (1975). Intention and Behavior: An introduction to theory and research.

[17] Fishbein, M., \&Ajzen, I. (1980). Predicting and understanding consumer behavior: Attitude-behavior correspondence. Understanding attitudes and predicting social behavior, 148-172.

[18] Franke, R. H., Hofstede, G., \& Bond, M. H. (1991). Cultural roots of economic performance: A research notea. Strategic management journal, 12(S1), 165-173.

[19] Galtier, V. (2005). Comment mesurer l'apprentissage de groupe? Construction d'une échelle de mesure bi-dimensionnelle (No. 123456789/4244). Paris Dauphine University.

[20] Gururajan, R., Toleman, M., \& Soar, J. (2004). Necessity for a new technology acceptance model to predict adoption of wireless technology in healthcare. HIC 2004: Proceedings, 87.

[21] Hofstede, G. (1980). Motivation, leadership, and organization: do American theories apply abroad?. Organizational dynamics, 9(1), 42-63.

[22] Hofstede, G. (1984). Culture's consequences: International differences in work-related values (Vol. 5). sage.

[23] Hofstede, G., \& Bond, M. H. (1988). The Confucius connection: From cultural roots to economic growth. Organizational dynamics, 16(4), 5-21.

[24] Hofstede, G., Hofstede, G. H., \& Arrindell, W. A. (1998). Masculinity and femininity: The taboo dimension of national cultures (Vol. 3). Sage.

[25] House, R. J., Hanges, P. J., Javidan, M., Dorfman, P. W., \& Gupta, V. (Eds.). (2004). Culture, leadership, and organizations: The GLOBE study of 62 societies. Sage publications.

[26] Hu, P. J., Chau, P. Y., Sheng, O. R. L., \& Tam, K. Y. (1999). Examining the technology acceptance model using physician acceptance of telemedicine technology. Journal of management information systems, 16(2), 91-112. 
International Journal of Managing Information Technology (IJMIT) Vol.11, No.3, August 2019

[27] Hubona, G. S., \&Geitz, S. (1997, January). External variables, beliefs, attitudes and information technology usage behavior. In Proceedings of the thirtieth Hawaii international conference on system sciences (Vol. 3, pp. 21-28). IEEE.

[28] Jolibert, A., \& Jourdan, P. (2006). Marketing research: méthodes de recherche et d'études en marketing. Dunod.s

[29] Jolliffe, I. (2011). Principal component analysis (pp. 1094-1096). Springer Berlin Heidelberg.

[30] Mitchell, A. A., \& Olson, J. C. (1981). Are product attribute beliefs the only mediator of advertising effects on brand attitude? Journal of marketing research, 18(3), 318-332.

[31] Moores, T. T. (2012). Towards an integrated model of IT acceptance in healthcare. Decision Support Systems, 53(3), 507-516.

[32] Ouiame, B. I., \& Khalid, C. Understanding the Impact of the Cultural Factors on Hospital Information System Acceptance: A Literature Review and Proposal of a New Model.

[33] OumlilR.(2010). Modèle de prédiction de l'appropriation des technologies de l'information et de la communication et des systèmes d'information par les professionnels de soins : cas de la ville d'Agadir, (Doctoral dissertation, Université Ibn Zohr Agadir, Maroc).

[34] Pai, F. Y., \& Huang, K. I. (2011). Applying the technology acceptance model to the introduction of healthcare information systems. Technological Forecasting and Social Change, 78(4), 650-660.

[35] Pelegrín-Borondo, J., Reinares-Lara, E., \&Olarte-Pascual, C. (2017). Assessing the acceptance of technological implants (the cyborg): Evidences and challenges. Computers in Human Behavior, 70, 104-112.

[36] Pett, M. A., Lackey, N. R., \& Sullivan, J. J. (2003). Making sense of factor analysis: The use of factor analysis for instrument development in health care research. Sage.

[37] Roussel, P., \&Wacheux, F. (2005). Management des ressources humaines: Méthodes de recherche en sciences humaines et sociales. De BoeckSupérieur.

[38] Schaper, L. K., \&Pervan, G. P. (2007). ICT and OTs: A model of information and communication technology acceptance and utilisation by occupational therapists. International journal of medical informatics, 76, S212-S221.

[39] Srite, M., \&Karahanna, E. (2006). The role of espoused national cultural values in technology acceptance. MIS quarterly, 679-704.

[40] Streiner, D. L. (2003). Starting at the beginning: an introduction to coefficient alpha and internal consistency. Journal of personalityassessment, 80(1), 99-103.

[41] Thiétart, R. A. (2014). Méthodes de recherche en management-4ème édition. Dunod.

[42] Thompson, B. (2004). Exploratory and confirmatory factor analysis: Understanding concepts and applications. American Psychological Association.

[43] Triandis, H. C. (1979). Values, attitudes, and interpersonal behavior. In Nebraska symposium on motivation. University of Nebraska Press.

[44] Tung, F. C., Chang, S. C., \& Chou, C. M. (2008). An extension of trust and TAM model with IDT in the adoption of the electronic logistics information system in HIS in the medical industry. International journal of medical informatics, 77(5), 324-335.

[45] Venkatesh, V., \& Davis, F. D. (2000). A theoretical extension of the technology acceptance model: Four longitudinal field studies. Management science, 46(2), 186-204.

[46] Venkatesh, V., Morris, M. G., Davis, G. B., \& Davis, F. D. (2003). User acceptance of information technology: Toward a unified view. MIS quarterly, 425-478.

[47] Weir, J. P. (2005). Quantifying test-retest reliability using the intraclass correlation coefficient and the SEM. The Journal of Strength \& Conditioning Research, 19(1), 231-240.

[48] Wu, J. H., Wang, S. C., \& Lin, L. M. (2007). Mobile computing acceptance factors in the healthcare industry: A structural equation model. International journal of medical informatics, 76(1), 66-77.

[49] Wu, L., Li, J. Y., \& Fu, C. Y. (2011). The adoption of mobile healthcare by hospital's professionals: An integrative perspective. Decision support systems, 51(3), 587-596.

[50] Yong, A. G., \& Pearce, S. (2013). A beginner's guide to factor analysis: Focusing on exploratory factor analysis. Tutorials in quantitative methods for psychology, 9(2), 79-94. 